4. Rappaport BA, Suresh S, Hertz S et al. Anesthetic neurotoxicity-clinical implications of animal models. N Engl J Med 2015; 372: 796-7.

5. Earp BD. Do the Benefits of Male Circumcision Outweigh the Risks? A Critique of the Proposed CDC Guidelines. Front Pediatr 2015; 3: 18

6. Cohen MS, Chen YQ, McCauley M et al; HPTN 052 Study Team. Prevention of HIV-1 infection with early antiretroviral therapy. N Engl J Med 2011; 365 493-505.

7. Vogt C, Eide ML, Hagmar B et al. Fremtidig organisering av celleprøver i laboratorier. En rapport utarbeidet av Gruppe Fremtid. 2013 https://helsedirektoratet.no/Documents/Kreft/09-3635-322\%20GRUPPE\%20\% 20FREMTID\%2023\%2010\%2013.doc\%2010609219_4_1.pdf (8.12.2015).

8. Van Howe RS. Sexually transmitted infections and male circumcision: a systematic review and meta-analysis. ISRN Urol 2013; 2013: 109846

9. Liu CM, Hungate BA, Tobian AAR et al. Male circumcision significantly reduces prevalence and load of genital anaerobic bacteria. MBio 2013; 4: e00076

10. Kinuthia RG. The Association between Female Genital Mutilation (FGM) and the Risk of HIV/AIDS in Kenyan Girls and Women [15-49 Years]. Public Heal. Theses. 2010. http://scholarworks.gsu.edu/cgi/viewcontent.cgi?article=1113\& context=iph_theses (8.12.2015)

\section{Re: Omskjæring av gutter}

Når en tidligere og nåværende redaktør i Tidsskriftet argumenterer for prioritering av rituell omskjæring i norsk helsevesen, forventer man høy kompetanse på vitenskapelig metode og diskusjon (1). Men de trekker frem studier på reduksjon av HIV i høyendemiske områder i Uganda og Kenya og mulighet for reduksjon av HPV, for å bringe medisinske argumenter inn i diskusjonen. Problemet er bare at striden om rituell omskjæring er en debatt om barns integritet og rettigheter, og om prioritering av inngrep uten medisinsk indikasjon i Norge. Med mindre forfatterne mener at gutter med muslimsk eller jødisk bakgrunn utgjør en særlig risikogruppe for smitte av HIV i Norge, det formoder vi at de ikke gjør - blir argumentet derfor meningsløst.

Med samme begrunnelse kan vi heller ikke se at argumentasjonen rundt HPV har noen relevans, med mindre man mener at alle norske gutter bør omskjæres. Mot HPV finnes det som Hem \& Bretthauer også påpeker effektiv vaksine, og det diskuteres nå om også gutter bør tilbys HPV-vaksine som del av vaksinasjonsprogrammet, på lik linje med jenter. Omskjæring uten tradisjonell kirurgi har også vært forsøkt lenge uten at det har fått stor plass, men å fremstille det som smertefritt synes lite reflektert. Når man sammenligner med komplikasjonsrate etter tonsilleoperasjoner, utelater man at førstnevnte må vurderes mot en medisinsk indikasjon, noe rituell omskjæring ikke har. Verken Anne Lindbo (2) eller forfatterne bør blande inn forhold rundt medisinsk indisert omskjæring i debatten, da det har lite med barns rettigheter eller prioritering å gjøre.

Enkelte kolleger har hevdet at nåløyet for å komme i Tidsskriftet er trangere enn i mange internasjonale journaler. Grunnen til at en setteredaktør likevel har gitt plass til dette manuskriptet kan vi derfor bare undres over. Noe verdifullt inn i debatten om rituell omskjæring i norske sykehus bringer det i hvert fall ikke.

\section{Erik Skaaheim Haug}

erik.haug@siv.no

Magne Dimmen

Erik Skaaheim Haug (f. 1967) er urolog ved Sykehuset i Vestfold. Ingen oppgitte interessekonflikter.

Magne Dimmen (f. 1972) er urolog ved Sykehuset Innlandet, Lillehammer. Ingen oppgitte interessekonflikter.

\section{Litteratur}

1. Bretthauer M, Hem E. Omskjæring av gutter. Tidsskr Nor Legeforen 2015; 135 1926-7.

2. Lindboe A. Vern også guttebarn mot omskjæring. NRK ytring 18.3.2015. www.nrk.no/ytring/vern-ogsa-guttebarn-mot-omskjaering-1.10953417 (8.12.2015).

\section{Re: Omskjæring av gutter}

M. Bretthauer \& E. Hem mener at det er god medisinskfaglig begrunnelse for at omskjæring av smågutter bør være en offentlig oppgave (1). Det er flere grunner til at dette ikke er riktig.

For det første peker de på at risikoen for komplikasjoner er lavere enn for tonsillektomi «som gjøres for å forhindre halsinfeksjoner og bedre nattesøvnen». Det er vel ingen som foretar primærforebyggende tonsillektomi - tvert om kreves det en god medisinsk begrunnelse ut fra kliniske funn og sykehistorien.

For det andre har ikke barn samtykkekompetanse, og Rådet for legeetikk har pekt på at det er medisinsk-etisk problematisk å utføre et irreversibelt kirurgisk inngrep som medfører smerte og risiko for alvorlige komplikasjoner, uten at det er medisinsk begrunnet (2). Det egentlige spørsmålet er om religiøs begrunnelse kan ha forrang i vurderingen av hva som er i barnets beste interesse.

For det tredje: Bretthauer \& Hem bygger i hovedsak sin begrunnelse på en rapport fra American Academy of Pediatrics (3), men burde også ha lest motargumentene i samme tidsskrift fra 38 spesialister fra 18 land (4). Rapportens begrunnelser, både om HIV og andre seksuelt overførbare sykdommer, er overført fra studiene om forebygging av HIV i høyendemiske land gjennom omskjæring av voksne menn (3). Resultatene er ikke overførbare til land som Norge. For eksempel er det påfallende at forekomsten av HIV er fem ganger høyere i USA enn i Norge og tilsvarende land, til tross for at de fleste menn i USA er omskåret $(5,6)$. Rapportens eneste medisinske begrunnelse for å anbefale omskjæring av spedbarn framfor unge voksne, er å redusere forekomsten av sykehusbekreftede urinveisinfeksjoner i spedbarnsalderen fra ca. $1 \%$ til $0,2 \%$. Forekomsten av urinveisinfeksjoner i 1. leveår i en 5-årsperiode i Hordaland var $0,14 \%$ ! (upublisert materiale).

For det fjerde skriver Bretthauer \& Hem at det er velkjent at det er større risiko for komplikasjoner når inngrepet gjøres hos eldre enn yngre gutter. De dokumenterer ikke påstanden, og jeg finner ingen referanser som bekrefter det. Som lege i Nord-Amerika har jeg utført mange omskjæringer hos spedbarn. Jeg vil påstå at det krever betydelig erfaring og rutine å utføre omskjæring på en sikker måte og med et resultat foreldrene er fornøyd med. Den beste måten å oppnå det på, er å overlate oppgaven til private helseforetak der inngrepet gjøres av et fătall leger. Ved de fleste norske sykehus vil ikke legene oppnå tilsvarende kompetanse. I Nederland utføres omtrent alle omskjæringer hos muslimske spedbarn av et privat helseforetak som har spesialisert seg på dette. De opplever $0,9 \%$ postoperativ blødning og 2,7\% sårinfeksjoner, noe de hevder er eksepsjonelt lavt i pålitelige oppfølgingsstudier. Prisen var 265 euro i 2014, og det betaler foreldrene (A. Klein, ansvarlig lege ved Besnijdenis Centrum, Nederland; personlig meddelelse).

\section{Trond Markestad}

trond.markestad@helse-bergen.no

Trond Markestad (f. 1945) er professor i barnemedisin ved Universitetet i Bergen, Barneklinikken, Haukeland universitetssykehus. Ingen oppgitte interessekonflikter.

Litteratur

1. Bretthauer M, Hem E. Omskjæring av gutter. Tidsskr Nor Legeforen 2015; 135 1926-7.

2. Rådet for legeetikk. Årsberetning for 2011. http://legeforeningen.no/Emner/ Andre-emner/Etikk/Arsberetninger-Radet-for-legeetikk/ (8.12.2015).

3. American Academy of Pediatrics Task Force on Circumcision. Male circumcision. Pediatrics 2012; 130: e756-85

4. Frisch M, Aigrain Y, Barauskas V et al. Cultural bias in the AAP's 2012 Technical Report and Policy Statement on male circumcision. Pediatrics 2013; 131: $796-800$.

5. Centers for Disease control and prevention. http://www.cdc.gov/mmwr/preview/ mmwrhtml/mm6424a2.htm?s_cid=mm6424a2_e\#Tab1 (29.11.2015)

6. Folkehelseinstituttet. www.fhi.no (29.11.2015). 